\title{
Seasonal Variation in Ground Water Quality at North Zone of Chalisgaon Taluka, Dist. Jalgaon (Maharashtra)
}

\author{
P.J. PARMAR \\ Department of Chemistry, Nanasaheb Y.N.Chavan College, Chalisgaon - 424101 (India).
}

(Received: May 20, 2012; Accepted: June 27, 2012)

\begin{abstract}
This study deals with assessement of Physico - Chemical Characterisations of ground water around Chalisgaon Taluka of Jalgaon district in Maharashtra. The study has been carried out to examine its suitability for drinking, irrigation and industrial purpose. Rapid urbanization which caused ground water pollution has affected the availability and quality of ground water due to its over exploitation and improper waste disposal. Groundwater pollution caused by human activities like runoff fertilizers, pesticides used in agricultural field, release of industrial waste water, percolation of surface water etc.

In the present study, attempts were made to investigate some Physico - Chemical Parameters of groundwater samples collected from seven wells at a distance of five to ten kms along north side of right Girna canal and Girna river from different locations of seven villages of Chalisgaon Taluka were studied in the span of June 2010 to Feb. 2012. The parameters pH studied includes temperature, electrical conductivity, total alkalinity, total hardess, calcium, magnessium, chloride, free $\mathrm{CO}_{2}$ total dissolved solid, dissolved oxygen. The study was carried out in each season for two consecutive years. The range of $\mathrm{pH}$ was found to be 7.45 to 9.19 which indicates that the water is alkaline. Other parameters are in the normal range but show variations drastically with the change in season. Detail variation in the range of values of parameters and possible causes are discussed. In case of underground water it was found that, conductivity, alkalinity and hardness were high and much over the permissible limits. The effect of long term continuous extensive irrigation by underground water and application of increasing amount of chemical fertilizers and insecticides over years on water and soil quality on this area have been discussed.
\end{abstract}

Key Words: Physico-Chemical Characters, Underground water, Well water and Canal water.

\section{INTRODUCTION}

From the literature survey it is known that no investigation has been done on the quality of underground water in Chalisgaon Taluka of Jalgaon District of Maharashtra State. Seven villages are selected for this study situated in North - East of the Jalgaon district on the right bank of Girna river at a distance of $12 \mathrm{Kms}$ from Chalisgaon town on state highway No. 211. The area under investigation is a notable cotton, sugarcane \& banana producing centres and all the crop fields of this area are being irrigated by Girna right canal surface water and underground water as per availability of water resources Generally double and at some places triple cropping are possible due to adequate irrigation facility for certain crops. The people of this locality reported that, for increasing the yield, the application of fertilizers and pesticides is also increasing since last 15 years, but the yield is not satisfactory and thus deterioration of underground water quality can not be ruled out. Hence present study has been under taken in order to assess the underground water quality of these villeges near the girna right canal.

\section{EXPERIMENTAL}

Seven villages of Chalisgaon blocks on the sides of Girna (right) canal and Girna river are 


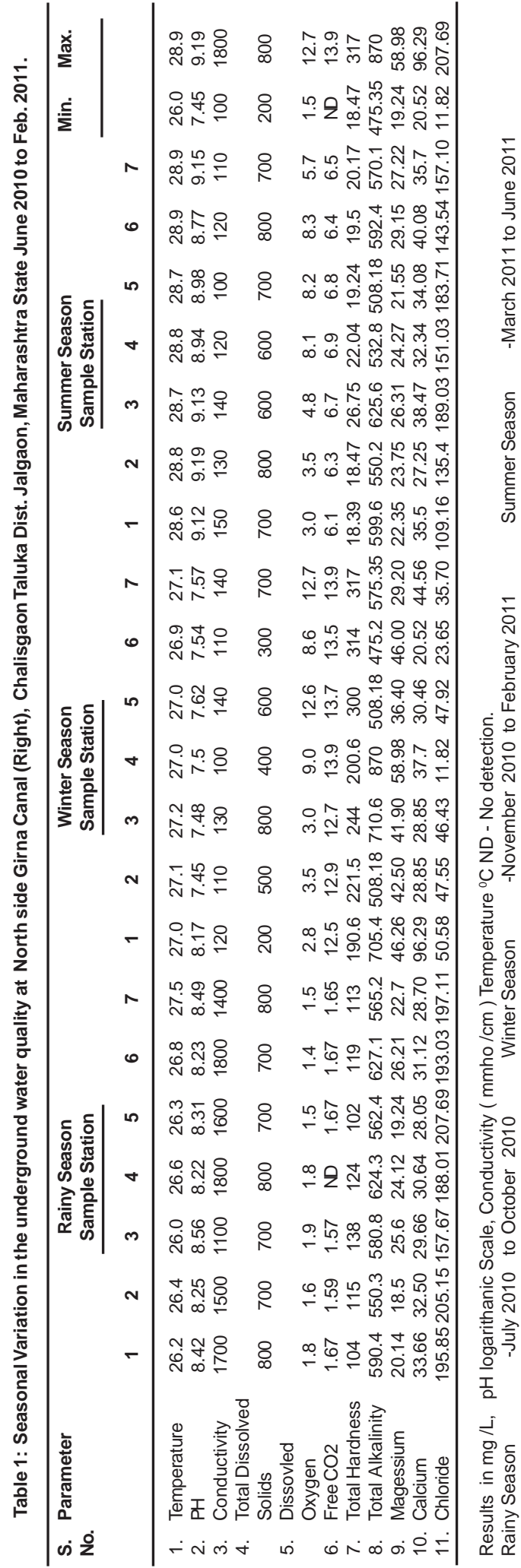

selected for the present study namely ${ }^{1}$ Dadpimpri 2 Umberkhede ${ }^{3}$ Mehunbare ${ }^{4}$ Bhaur $^{5}$ Vadgaonlambe ${ }^{6}$ Dhamangaon and ${ }^{7}$ Khedgaon.

The selection of wells from these villeges were at a distancd of about $05 \mathrm{Kms}$ from each sampling point along the north side of the canal. The underground water samples were collected from deep wells from these villeges on the basis of their agricultural importance. While collecting the samples; the electrical pumps were run for one minute and then water sample was collected in screw cappled polythene can previously cleaned and washed with deionised water and again rinsed with the same water sample several times.

The Underground water samples collected in the spell of June 2010 to Feb. 2012 in each rainy, winter and summer seasons. The water from wells of at a distance of about 5 to $6 \mathrm{~km}$. north to the canal which on irrigation given good yield was also collected for reference.

\section{RESULTS AND DISCUSSION}

Various water samples are collected from different sampling stations during every season was analysed. Eleven Physico- Chemical Parameters of water samples were determined and recorded. The termperature of the sample was noted at the sample spot during collection. At the same time the dissolved oxygen was fixed by the Chemical Process Methodology for water analysis by Dr. Mohan S. Kodarkar (1992). Other parameters like electrical conductivity, $\mathrm{pH}$, total alkalinity, total dissolved solids, Total hardness, calcium, magnessium, chloride, free $\mathrm{CO} 2$ were measured with in time span of three hours from sampling. The parameters were analysed by prescribed standard method given in (APHA and AWWA 1995, Trivedi \& Goel 1986,Jackson 1958, \& Kotaian and Sreedhar Reddy 2003).

A complete chemical analysis may determine the suitability of ground water for drinking agriculture irrigation and industrial purpose. The analysis of ground water sample includes the determination of concentration of the inorganic constituents present in addition to the measurement of $\mathrm{pH}$. electrical conductance, total dissolved solids 


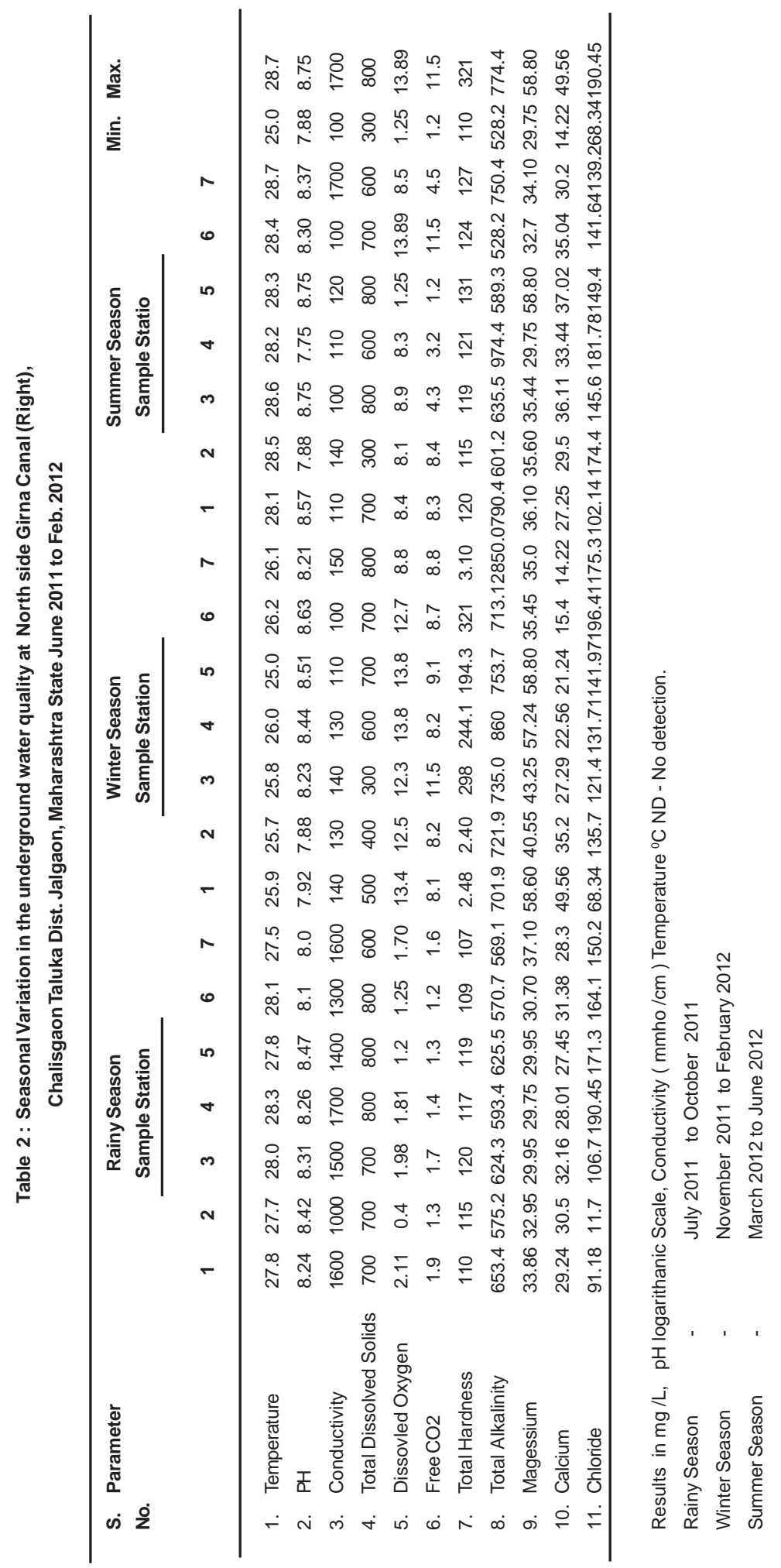


and other minor constituents. Each of these properties is useful in evaluating the chemical character of underground water. This water quality is also influenced by meteorological factors such as rainfall, evaporation etc. Therefore, it needs a constant monitoring of chemical parameters through out the year. In the present study, underground water from seven wells tapping various aquifer formation in area have been sampled and analysed for a period of two years in rainy, winter and summer season.

The variation in the concentration of mejor ion is shown in table 1 and 2 From these figures it is evident that the concentration of all the ions in winter season were low and exhibiting increasing trend in rainy and summer seaons. The reason for these changes could be the dissolution of salts and minerals which are present in soil due to the rise in water table during winter period. Kripanidhi (1984) have reported similar trends in ground water of a typical hard rock terrain and pollution in villages well in Karnataka State, India respectively.

Physico - Chemical Parameters of ground water samples of north side of canal from various sampling points are given in table -1 along with miniumum and maximum values while these of water sample of a long distance towards north side of canal are given in Table 2.

It was found that the termperature of wells of the villeges of Chalisgaon Taluka varies within about 30C during June 2010 to Feb. 2012 and average temperature of seven wells was $27.42^{\circ} \mathrm{C}$ in all seasons for both the years. Various chemical and biological reactions in water depends to great extent on temperature. The observed values of temperature indicates that the water quality would be certainly affected by this parameter. The $\mathrm{pH}$ of water varies between 7.45 to 9.19 . It is observed that except in winter, $\mathrm{pH}$.of all remaining samples was high particularly in summer, but on an average $\mathrm{pH}$ of all samples was in desirable limit as prescribed for drinking water standard (ICMR pH = 8.5). The average $\mathrm{pH}$ of all water samples from sampling stations were within the maximum permissible limit. It is known that $\mathrm{pH}$ of ground water does not reported by causes any severe health hazard reported by (Pujan \& Sinha 1999)
The specific conductivity of samples under study varies between 100 to $1800 \mathrm{~m} \mathrm{mho} / \mathrm{cm}$. the maximum permissible limit of this parameter for drinking water is $300 \mathrm{~m}$ mho $/ \mathrm{cm}$ but average specific conductivity exceeds this limit because of it's high values during each rainy season. In rainy season due to floods containing high electrolytes in water the conductivity of samples increases drastically ( reported by - Pujari \& Sinha 1999).

The sandard TDS in the water should below $1000 \mathrm{mg} / \mathrm{L}$ to consider it as non saline and values of water above this limit makes its nonpalatable ( reported by - Pujari and Sinha 1999). The permissible limit of TDS of drinking water is $500 \mathrm{mg} / \mathrm{L}$ (WHO). This observation shows that the TDS is higher in comparision to WHO recommendation but was non saline and palatable.

According to (kudesia 1985) good water quality have solubility of oxygen 7.0 and $7.6 \mathrm{mg} / \mathrm{L}$ at $30^{\circ} \mathrm{C}$ and $35^{\circ} \mathrm{C}$ respectively but except in rainy season all the sample showed higher values of D.O. Low values of D. O. in rainy season can be due to high values of conductivity of water.

Free $\mathrm{CO} 2$ content in well water is due to rain from plant roots and decaying vegetation ( reported by - Pujari and Sinha 1999). The factors responsible for solubilisation of $\mathrm{CO} 2$ are temperature, pressure, $\mathrm{pH}$ and total alkalinity ( reported by - Johnson 1996) The free CO2 contents of water of different wells varies from 0 to $13.9 \mathrm{mg} /$ L. However, the permissible limit of free $\mathrm{CO} 2$ has not yet been prescribed.

Hardness has no known adverse effect on health ( reported by - Pujari and Sinha 1999) However maximum permissible level has been prescribed for drinking water is $500 \mathrm{mg} / \mathrm{L}$ by WHO According to same classification water having hardness upto $75 \mathrm{mg} / \mathrm{L}$ is classified as soft water $76-150 \mathrm{mg} / \mathrm{L}$ is moderately soft water, $151-300$ $\mathrm{mg} / \mathrm{L}$ as hard water (reported by - Twort 1974) on the basis of this observations the results shows that,

1. All the water samples in rainy season were moderately soft.

2. Most of the observation in winter season showed that water was of moderately hard 
level.

3. In summer of 2010-2011 the observation showed that the water samples were soft but in summer of 2011-2012 water was moderately soft.

The total alkalinity of well water in terms of CaCO3 varied between 475.35 to 870 . These values of total alkalinity were comparatevely large in quantity as compared to those reported by and Pujari and Sinha in 1999. Rajaramohanpur and Silguri (2003), but it itself is not harmful to human health rather it provide buffering action. The water for domestic use having alkalinity less than $100 \mathrm{mg}$ / $L$ is safe ( reported by - Goel \& Trivedi 1986). The high content of alkalinity is evident in this particular area.

Present investigation shows the concentration of calcium in the water samples in the range of 20.52 to $96.29 \mathrm{mg} / \mathrm{L}$. during year June 2010 to Feb. 2011 and in the ragne of 14.22 to 49.56 during June 2011 to Feb. 2012. According to Ohle W. (1956), the waters above. Calcium values $25 \mathrm{mg}$. / $\mathrm{L}$ are classified as calcium rich. Thus as per the recommendations of ohle w. most of the water samples are 'Calcium rich'. The observed values of magnessium were between 19.24 to $58.98 \mathrm{mg} / \mathrm{L}$ during June 2010 to Feb. 2011 and 29.75 to $58.80 \mathrm{mg} / \mathrm{L}$. during June 2011 to Feb. 2012. This observations shows that maximum content of magnessium occured during winter. According to ISI and WHO standards the desirable maximum permissible values of magnessium content s for drinking water prescribed by $80 \mathrm{mg} /$ $\mathrm{L}, 50 \mathrm{mg} / \mathrm{L}$ and $30 \mathrm{mg} / \mathrm{L} 150 \mathrm{mg} / \mathrm{L}$ respectively Results of present investigation shows that the magnessium contents in mejority of samples does not exceed the limit as prescribed by ISI as well as $\mathrm{WHO}$.

Chlorine contents in water samples were in small quantity in rainy season and in very small quantity in winter season. According to $\mathrm{WHO}$, the maximum permissible limit for chloride is $500 \mathrm{mg} /$ $L$ and since the values observed in present study are well below this level it has not imparted the test for water. This investigation of Physico- Chemical Parameters of water samples indicate that
Dissolved oxygen is well below the permissible limit but total alkalinity and total specific conductivity exceed the permissible limit. All remaining parameters are well within the limit. This indicates that no doubt water is contaminated but contamination is not of greater extent so far due to the agricultural practices followed by the people. Hence on the basis of above favourable results, water from these area are best suited for drinking irrigation \& industrial application.

A study of Physcio- Chemical charcterisation of underground water at a distanced of 5 to $10 \mathrm{Km}$. north to canal taken in winter season shows the correlation with the data of winter season of underground water from sampling sites near the canal. This study indicates that north side of underground water does not have any impact of canal on its Physico - Chemical Characters.

\section{Mechanism controlling the chemistry of ground water}

Conway (1984), Garham (1961), Garrels and Christ (1965, 1966), Gibbs (1970) and Ramesam and Barua (1973) have discussed in detail the mechanism controlling the chemistry of fresh water. The hydrochemical studies are being used to establish the relationship of water composition to aquifer litholgoy. This helps not only to explain the origin and distribution of disssolved constituents but also to elucidate the factors controlling the groundwater chemistry. As per the classification of Gibbs (1970), the major natural mechanisms controlling world surface ground water chemistry are admospheric preciptitation, rock weathering evalovation and fractional crsytalization.

\section{ACKNOWLEDGEMENTS}

Auther is thankful to the Management of R.S.S.P. Mandal Ltd., Chalisgaon, Dist. Jalgaon Sanstha's Nanasaheb Y. N. Chavan Arts, Science, and Commerce College, Chalisgaon, Dist. Jalgaon (424101), for providing necessary laboratory facilities. Thanks are also due to The Management and Principal of the same college for overall help and constant encouragement throughout the present investigation. 


\section{REFERENCES}

1. APHA and AWWA, Standard methods for the examination of water and water and waste water, 16th edition, Washington D.C. (1995)

2. Bandela N. N, Physico - chemical projects of Barual Dam of Kandhar, Theiss submitted to Dr. B. A. M. University, Aurangabad. (1998)

3. Kotaish B and Sreedhar Reddy S, Indian J. Environ. and Ecoplanm. 7(1): 43-46 (2003)

4. Conway E. J, Mean geo-chemical data in relation to oceanic evolution. Proc. Irish Acad., 48: 119-159 (1984).

5. Garham E, Factors influencing suply of major ions to inland water special reference to atmospheric; Bull Geo Soc Amer, 72: 795480 (1965)

6. Garrels R. M. and Christ C. L. Solutions Minerals and Equilibria, Harper row, New York (1965)

7. Gibbs R.J., Machanism Controlling water chemistry, 170: 1088-1090 (1970)

8. Gopal Krishna Pujari and Sinha B. K, Journal of Env. and Pollution, 71-76 (1999)

9. ICMR standards, standard methods for examination of water (1985)

10. ISI and WHO, Indian Standards of drinking water specification, Bureau to Indian Standards New Delhi, 2-4, BIS 10500 (1992)

11. Jackson M. L., Soil Chemical Analysis, Prentice Hall Pvt. Ltd., New Delhi, India. (1958)

12. Kudesia V. P., Water Pollution, Pragati Prakashan, Meerut (1985)

13. Kripanidhi K. V. J. R. Mechanism of Ground water pollution in village wells, Geological Society of India, 25: $301-302$ (1984)

14. Mohan S. Kodarkar, Methodology of water analysis., (1992)

15. Ohle W, 'Bioactivity production and engergy utilization of lakes' Limnal and Ocenog., 1: 139-149 (1956).
16. Raja Rammohanpur Siliguri, J. Environ Biol, 24(2): 125-133 (2003).

17. Trivedi R. K and Goel P. K, Chemical and Biological methods for water pollution studies, Environment publications, Karad (1986)

18. Twort, A.C., Hoather R.C and Law F. M. Water supply, Edward Ornold Pub. Ltd., Londan (1974).

19. WHO, Guideline for drinking water quality, recommendation World Health Organization, Geneva 1: (1984).

20. Chavan T. P., Physico - Chemical Characteristics of Water and Soil, Ph.D. Thesis Dr. B. A. M. University, Aurangabad (2000).

21. Shah, A. R., Physico- Chemical aspects of pollution in river Jhelum (Kashmir) during (1981-83). In Trivedy, R. K. Edited Ecology and Pollution of Indian rivers 163- 207 (1988).

22. Raymahashay, B.C. Geochemistry of biocarbonates in river water, Great Soc. of India, 27: 114-118 (1986)

23. Pujari and Sinha B. K. Journal of Environment and Pollution, 6(i): 71-76 (1999). (Technoscience Publication )

24. Prasad, B.V. and Rameshchandra P., Ground Water Quality in an Industrial Zone. A case study, Poll. Res. 16(2) : 105-107, (1997)

25. Pandhe, G. M., Dhembare A.J. and Patil R. P., The Physichemical Characteristic and quality of water from the Pravara area, Ahemadnagar District, Maharashtra, J. Aqua. Biol. 10(1) : 43-48 (1995).

26. G.S. Kabwania and Radhey Shyam. Orient. J. Chem. 28(1): 547-552 (2012).

27. K.C. Gupta and Jagmohan Oberoi. Orient. J. Chem. 26(1): 215-221 (2010). 